\title{
Rural Public Libraries and Digital Inclusion: Issues and Challenges
}

\begin{abstract}
Rural public libraries have been relatively understudied when compared to public libraries as a whole. Data are available to show that rural libraries lag behind their urban and suburban counterparts in technology service offerings, but the full meaning and effect of such disparities is unclear. The authors combine data from the Public Library Technology and Access Study with data from smaller studies to provide greater insight to these issues. By filtering these data through the digital inclusion framework, it becomes clear that disparities between rural and nonrural libraries are not merely a problem of weaker technological infrastructure. Instead, rural libraries cannot reach their full customer service potential because of lower staffing (but not lower staff dedication) and funding mechanisms that rely primarily on local monies. The authors suggest possible solutions to these disparities while also discussing the barriers that must be overcome before such solutions can be implemented.
\end{abstract}

\section{INTRODUCTION}

The large number of rural public libraries in the United States is surprisingly understudied, particularly in terms of technology access. The American Library Association (ALA) and other professional organizations consider a public library to be small or rural if its population of legal service area is 25,000 or less. When viewed through this lens, rural public libraries ${ }^{1}$

- have on average less than one (.75) librarian with a master's degree from an ALAaccredited institution;

- have an average of 1.9 librarians, defined as an employee holding the title of librarian;

- have an average total of 4.0 staff, including both full- and part-time employees;

- have a median annual income (from all sources) of $\$ 118,704.50$;

- have an average of 41,425 visits annually; and

- typically have one building or branch that is open an average of 40 hours/week.

Brian Real (breal@umd.edu) is a PhD candidate in the College of Information Studies, John Carlo Bertot (jbertot@umd.edu) is Co-Director of the Information Policy and Access Center and Professor in the College of Information Studies, and Paul T. Jaeger (pjaeger@umd.edu) is CoDirector of the Information Policy and Access Center and Associate Professor and Diversity Officer of the College of Information Studies, University of Maryland, College Park, Maryland. 
While these data suggest rural libraries operate on a smaller and less financially robust scale than their suburban and urban counterparts, the full effect of these discrepancies on service levels is unclear. This article uses various information sources to analyze the effect of these discrepancies on the ability of rural libraries to offer technology-based services.

Since the advent of the Internet in the mid-1990s, public libraries have been key Internet-access and technology-training providers for their communities. The ability to offer Internet access alongside support and training for patrons using such technology are primary indicators of libraries' value to their communities. By analyzing data from the 2012 Public Library Funding and Technology Access Survey (PLFTAS), the authors found that rural libraries, on average, have weaker technological infrastructure (such as fewer average numbers of computers and slower broadband connections) and are able to offer fewer support services, such as training classes, than urban and suburban public libraries.

With public libraries being many patrons' only source of broadband access in many rural communities, limitations for rural libraries may affect patrons' ability to fully participate in employment, education, government, and other central aspects of society. Through analysis of the PLFTAS data ${ }^{2}$ about technology access in rural public libraries in conjunction with other studies of rural libraries and librarians, this article explores the causes and effects of the relatively more limited technological and support infrastructures for rural patrons and communities.

\section{METHOD}

As documented since 1994, ${ }^{3}$ public libraries were early adopters of Internet-based technologies. The purpose of the PLTAS survey, and its previous iterations, is to identify public library Internet connectivity; propose and promote public library Internet policies at the federal level; maintain selected longitudinal data as to the connectivity, services, and deployment of the Internet in public libraries; and provide national estimates regarding public library Internet connectivity. Through changes in funding sources and frequency of administration over the past two decades, the survey has maintained core longitudinal questions (e.g., numbers of public access workstations, bandwidth), but consistently explored a range of emerging topics (e.g., jobs assistance, e-government, emergency roles).

The survey's method has evolved over time to meet changing survey data goals. The 2012 survey provides both national and state estimates of public library Internet connectivity, public access technologies, and Internet-enabled services and resources. The survey used a stratified "proportionate to size sample" to ensure a proportionate national sample using the FY2009 IMLS public library dataset (formerly maintained by the US National Center for Education Statistics) to draw its sample. Strata included states in which libraries resided and metropolitan status (urban, suburban, rural) designations. Bookmobile and books by mail service outlets were removed from the file, leaving 16,776 library outlets. 
The study team drew a sample with replacement of 8,790 outlets stratified and proportionate by state and metropolitan status state. ${ }^{4}$ The survey received 7,252 responses for a response rate of $82.5 \%$. Using weighted analysis to generate national and state data estimates, the analysis uses the responses to estimate to all public library outlets (minus bookmobiles and books by mail) in the aggregate as well as by metropolitan status designations. Unless otherwise noted, all data discussed in the article are from the 2012 study. That study, along with all previous Public Libraries and the Internet and Public Library Funding and Technology Access studies, additional analysis, and data products are available at http://www.plinternetsurvey.org.

\section{Digital Inclusion and the Value of Public Libraries}

Digital inclusion is a useful framework through which one can understand the importance of ensuring individuals have access to digital technologies as well as the means to learn how to use them. ${ }^{5}$ Digital inclusion comprises policies and actions that mitigate the significant, interrelated problems of the digital divide and digital literacy:

- Digital divide implies the gap-whether based in socioeconomic status, education, geography, age, ability, language, or other factors-between individuals for whom Internet access is readily available and those for whom it is not. Indeed, even those with basic, dialup Internet access are losing ground as Internet and computer technologies continue to advance, using increasing bandwidth and demanding high-speed ("broadband") Internet access.

- Digital literacy encompasses the skills and abilities necessary for access once the technology is available, including understanding the language and component hardware and software required to successfully navigate the technology.

- Digital inclusion is policies developed to close the digital divide and promote digital literacy. It marries high-speed Internet access (as dial-up access is no longer sufficient) and digital literacy in ways that reach various audiences, many of whom parallel those mentioned within the digital divide debate. To match the current policy language, digital inclusion will signify outreach to unserved and underserved populations.

Since virtually every public library in the United States offers public Internet access, these institutions are invaluable in promoting digital inclusion. However, the PLFTAS data shows that not all libraries are equal, with rural public libraries lagging behind libraries in more populated areas in providing technology services. Therefore this article focuses on the following issues and questions:

- Digital divide: Why do rural individuals have less access to broadband technologies than their suburban and urban counterparts? How are rural libraries currently compensating for this deficit? 
- Digital literacy: Why do rural libraries offer less digital literacy training and patron support? How do rural libraries compare to libraries in more populated areas on key issues in digital literacy, such as employment and government information?

- Digital inclusion: What policies have been developed to help rural libraries close the digital divide and promote digital literacy, and what policies-including funding structures and decisions-hinder these libraries from adequately addressing these concerns? What governmental and extra-governmental policies can be enacted to help rural libraries to better promote digital inclusion?

The following section describes the differences between rural libraries and their urban and suburban counterparts, combining PLFTAS data with information from other studies to demonstrate how rural libraries are more essential in bridging the digital divide yet are seemingly doing less to promote digital literacy. Following this, the authors discuss why rural libraries trail suburban and urban libraries in these areas, with studies suggesting the issue is a result of inadequate resources, not a lack of staff dedication. Finally, the authors present a review of some of the initiatives that are attempting to bridge these divides, including suggestions that may help rural librarians to act as better advocates for their patrons' needs.

\section{Rural Challenges to Digital Inclusion}

Numerous studies, including PLFTAS, show that rural libraries offer less technology access with slower connection speeds than libraries in more populated areas. These libraries also offer comparatively less formalized digital literacy training, although rural libraries still provide invaluable informal training in this area. This section highlights discrepancies between rural libraries and those in more populated areas.

\section{Technology and Service Disparities between Rural and Nonrural Libraries}

While almost every public library offers patrons Internet access, $70.3 \%$ of rural libraries are the only free Internet and computer terminal access providers in their service communities, compared to $40.6 \%$ of urban and $60.0 \%$ of suburban libraries. ${ }^{6}$ The disparity between these categories becomes more striking when one considers the difference between home broadband adoption in rural and nonrural areas. According to the Pew Research Center's Home Broadband 2010 survey, only $50 \%$ of rural homes have broadband Internet access, compared to $70 \%$ of nonrural homes. ${ }^{7}$

This disparity is due in large part to the greater difficulty and cost of creating the infrastructure to support broadband Internet access in more sparsely populated areas. ${ }^{8}$ With broadband access provided primarily by for-profit companies, little profit motive exists to expand services to areas where the infrastructure cost would not allow for a quick and efficient recouping of costs. The US Government has attempted to address this problem in a numerous ways, including dedicating $\$ 7.2$ billion to improving broadband access throughout the country through grants (Broadband 
Technology Opportunity Programs; BTOP) and loans (Broadband Infrastructure Projects; BIP) as part of the American Recovery and Reinvestment Act (ARRA) of 2009. ${ }^{9}$ Expanding this infrastructure will take time, and at this time it is unknown as to the extent to which broadband access in rural communities, both in general and for public libraries, will increase. As the ARRA projects near completion, it will be important to conduct follow-up analysis of the effect in terms of access to broadband in the home and in anchor institutions such as public libraries, as well as the extent to which broadband subscriptions increased.

At present, however, public libraries - and rural public libraries in particular-are still the primary source of broadband access for many Americans, and this will likely remain true for large portions of the population for the foreseeable future. Individuals in need of Internet access have few options in many communities. Though there are increasing free wireless (Wi-Fi) Internet access sources in communities (e.g., coffee shops, food outlets), one needs to have a device (e.g., tablet, laptop) to use these options. In two-thirds of American communities, the public library is the only source of freely available public Internet access inclusive of public access computers. ${ }^{10}$ Specific government efforts to increase Internet access, broadband networks, and digital literacy of the population, however, fail to involve public libraries in a meaningful way, if at all. ${ }^{11}$

To be fair, public libraries were eligible to compete for the grants or submit loan applications for the ARRA broadband funding initiatives, and public libraries in states such as Alaska, Arizona, Colorado, Idaho, Maine, Montana, Nebraska, and others have benefited from this, primarily through inclusion in applications with multiple beneficiaries. ${ }^{12}$ Since BTOP works as a grantmaking process, relatively few US public libraries (approximately 20\%) have benefited from BTOP funding, but the results have been encouraging. For example, 85 libraries in mostly rural Nebraska have upgraded their broadband capacity using BTOP funds, with broadband capacity for these locations increasing from an average of $2.9 \mathrm{Mbps}$ to an average of $18.2 \mathrm{Mbps}$. Other states have tried innovative ideas, such as the Idaho Department of Labor's Youth Corps program to train high school and college students to work as digital literacy coaches, and then deploy them to libraries around the state. Indeed, the BTOP program has certainly created some encouraging results, but this is not a permanently funded program and it targets a limited number of libraries, so it cannot be considered as a primary, widespread solution to the digital inclusion gap between rural and more populated areas. The authors of a recent BTOP report note, "Unless strategic investments in U.S. public libraries are broadened and secured, libraries will not be able to provide the innovative and critical services their communities need and demand." 13 Thus BTOP may provide a good model to addressing gaps in digital inclusion, but it was never designed to be a permanent solution.

This role of ensuring digital inclusion in communities has accelerated at a time of unprecedented austerity nationally and at the state and local levels of government in particular. Based on Bureau of Labor Statistics (http://www.bls.gov) data, the United States lost 584,000 public-sector jobs between June 2009 and April 2012, or 2.5\% of the local, state, and federal government jobs that 
existed before the prolonged economic downturn began. According to the Center on Budget and Policy Priorities, state budget shortfalls have ranged from $\$ 107$ billion to $\$ 191$ billion between 2009 and 2012, and current projections place state budget shortfalls at $\$ 55$ billion for $2013 .{ }^{14}$ The prolonged economic downturn, in part, has driven up library usage in some communities. ${ }^{15}$

Even before the downturn began, public libraries in the rural areas typically had the oldest computing equipment, the slowest Internet access speeds, and the lowest support levels from the federal government. ${ }^{16}$ As a part of becoming the main source of digital literacy training and digital inclusion, public libraries have also become a primary training provider for in-demand, technology-based job skills. ${ }^{17}$ The resulting situation forces public libraries to balance reduced support, increased demand, and a growing centrality in helping their communities recover from the economic downturn. At the center of both increased demand and increased support of digital literacy and inclusion lies sufficient Internet access.

In a survey of rural librarians in Tennessee, respondents reported that their patrons' most critical information need was broadband Internet access. ${ }^{18}$ The respondents also ranked access to recent hardware technology and software, technology training, and help with specific tasks like applying for jobs or government benefits as highly critical. By comparison, the respondents ranked traditional services such as book loaning as the least critical duty, significantly trailing the abovementioned and other technology services. Despite rural librarians viewing technology-based services as their most important function, however, rural libraries lack the resources to meet the same service quality as nonrural libraries. The ensuing section discusses the nature of those disparities.

\section{Technology Infrastructure and Technology Training}

Virtually all public libraries offer their patrons access to the Internet. There is no statistical difference between rural, suburban, and urban libraries in this regard. ${ }^{19}$ Likewise, rural libraries only lag slightly in wireless Internet availability, which is becoming increasingly important with the ubiquity of mobile technology devices; $86.3 \%$ of rural libraries have wireless access available for patrons, compared to an average of $90.5 \%$ across all three categories. ${ }^{20}$ And, in one of the few technological areas where rural libraries lead their nonrural counterparts, $42.3 \%$ of rural libraries reported they had sufficient public access computer terminals at all times, compared to $33.5 \%$ of suburban and $12.9 \%$ of urban libraries.

While the number of rural library computer terminals may be adequate in many locations, hardware quality suffers; $69.5 \%$ of rural libraries replace their public access computer terminals as needed while, $66.4 \%$ of urban libraries have a technology replacement schedule. ${ }^{21}$ For many small libraries with only a single full-time librarian, that employee also serves as the IT specialist for the location. ${ }^{22}$ Therefore many rural libraries have less up-to-date technologies and less technical support than their nonrural counterparts. Even if the librarians who also provide IT support for their locations are qualified to fulfill this role, the greater issue is limited time for 
librarians to work on these issues in addition to other duties. In addition to less recent hardware, rural libraries also have limited bandwidth; 31.1\% of rural libraries operate on bandwidths of 1.5 Mbps (T1) or less, compared to only $18.3 \%$ of suburban libraries and a mere $9.7 \%$ of urban libraries. ${ }^{23}$

The greatest issues facing rural libraries are not well represented by the broader categories of Internet access but instead in the implementation of services to make these technologies highly useful and effective for patrons. Only 31.8\% of rural libraries offer formal technology training classes, as compared to $63.2 \%$ of urban and $54.0 \%$ of suburban libraries. ${ }^{24}$ This comparison alone does not present a problem, since more populated areas have larger customer bases that justify training patrons in groups rather than in one-on-one sessions. However, rural libraries also trail significantly in offering one-on-one technology training, with only $30.1 \%$ of rural libraries providing such programs, compared to $43.4 \%$ of urban and $37.9 \%$ of suburban libraries. Only $21.9 \%$ of rural libraries have online training materials, compared to $36.3 \%$ and $33.7 \%$ of urban and suburban libraries, respectively. In fact, $12.5 \%$ of rural libraries do not offer planned technology training at all, compared to a mere $5.1 \%$ of urban libraries and $8.0 \%$ of suburban libraries. Therefore, while most patrons in nonrural areas who have limited technology skills can go to their local library and acquire such skills for free, such access to the resources for personal advancement is drastically limited by comparison in rural areas. Since many rural residents do not have Internet access in their homes, many of these individuals do not own computers and have limited technology skills resulting from limited technology exposure. This makes the technology training disparity between rural and nonrural libraries quite problematic, since most Americans need these skills to maintain a high standard of living and employment.

\section{Employment Assistance}

While public libraries in all areas saw adequate staffing as a statistically similar problem for helping patrons find jobs- $51.9 \%$ or rural librarians agreed this was a challenge, only slightly exceeding the overall average of $49.8 \%$ - the greater issue is the disparity of confidence levels in assisting patrons in employment matters. ${ }^{25}$ Nearly half (48.3\%) of rural survey respondents agreed a lack of staff expertise was a challenge to helping patrons find and apply for jobs online, compared to $27.9 \%$ of urban and $37.7 \%$ of suburban libraries. The Internet has become essential for many people who wish to gain employment, thus rural public librarians' inability to support rural residents with limited technology skills is problematic. Many government agencies, hospitals, and private employers - including Walmart, the largest employer in the United States-will no longer accept paper applications, but instead insist potential employees submit applications via the Internet. ${ }^{26}$ This can be especially challenging for individuals who have recently lost jobs they have held for decades, as they simultaneously need to refresh basic application and interviewing skills while learning how to use unfamiliar information technologies to find and apply for jobs. Librarians can offer critical assistance in these cases, especially for individuals who do not own a computer or have Internet access in their homes. However, inequities in staffing between rural 
and nonrural libraries can prevent rural residents from having equal access and aid in finding careers.

\section{Government Service Access}

Rural libraries also lag behind libraries in more populated areas in providing support for accessing online government services. There is no statistically significant difference between public libraries in staff providing assistance to patrons who need help filling out forms, with $96.6 \%$ of all libraries offering this service. ${ }^{27}$ However, only $45.6 \%$ of rural libraries assist customers in understanding government programs and services, compared to $57.8 \%$ of urban and $52.9 \%$ of rural libraries. Rural libraries are also far less likely to have formal guides to help customers understand these government services, with only $15.3 \%$ of rural libraries offering such products as compared to $33.6 \%$ of urban and $22.2 \%$ of suburban counterparts. Just $6.2 \%$ of rural libraries offer formal training classes for using government websites, understanding government programs, and completing forms. Roughly a one-fourth $(24.5 \%)$ of urban and $11.9 \%$ of suburban libraries offer such services. In terms of staff expertise, $20.0 \%$ of rural libraries reported having at least one staff member with significant knowledge and expertise of government services, compared to $31.4 \%$ of urban and $25.0 \%$ of suburban libraries.

Therefore, while most public libraries help patrons access government services, rural libraries lag substantially in the type of formal planning that may make patrons more aware of government services that would improve their quality of life. Important services such as voter registration, motor vehicle services, payment of taxes, and school enrollment for children can now be done either only or much more efficiently online. ${ }^{28}$ These online services are more convenient for many Americans, but "while many members of the public may struggle with accessing or using egovernment information and services, government agencies have come to focus on it as a means of cost savings rather than increasing access for members of the public." ${ }^{29}$ Government agencies have for the most part not taken many Americans' lack of digital literacy into account when shifting their primary means of service to the digital realm, nor have they considered the effect this shift has on public libraries as the primary Internet provider for many Americans. This has led to extra responsibilities for rural public libraries but not a direct increase in resources.

One might consider that rural libraries offer fewer of these services, or have less expertise in providing digital government services, in part because such services are not in demand by patrons. However, government services have steadily moved online and the pace is accelerating towards an e-only means of interacting with government. The Open Government movement, 30 combined with the federal government's release of the technology and services blueprint, signals the further use of technologies to offer innovative and operational digital government services-both through more traditional web-based services and mobile applications. ${ }^{31}$ And state and local governments are increasingly engaging in e-government services such as unemployment and social service benefits, taxation, licensing, and more. In short, federal, state, and local governments are moving rapidly to a range of e-services that will necessitate facility by librarians with technologies, 
government services, and government information to better help their communities navigate the challenges of e-government.

\section{Government Intervention in Digital Literacy}

Although most government agencies have not considered the effect their shift to primarily digital services has on individuals who lack basic digital literacy, the Federal Communications Commission launched two programs that could help with the digital literacy problem. The first of these, DigitalLiteracy.gov, is designed to provide individuals with tools to facilitate digital inclusion, helping users to acquire skills that will make them more capable in the modern information environment. The challenge with this approach is that many resources on the website are designed for individuals who need such skills and who therefore probably do not have access to the Internet or possess the skills to fully engage the resources. Moreover, most of these resource links point to external sites, which are organized by arbitrary user ratings rather than skill level and relevance. ${ }^{32}$ Likewise, educator resources - which should be most valuable in helping librarians to education patrons - are presented as links to external sites with limited information about each resource. These resources may be able to help patrons, but a collaborative effort that includes public librarians in creating resources could better target particular patron needs in a public access setting.

A newer project, Connect2Compete, demonstrated more promising progress in this area. Connect2Compete is a partnership between the FCC and private businesses to provide low-cost Internet and computers to low-income families, digital literacy training, and other services. ${ }^{33}$ They also publicize the digital literacy divide, working with the Ad Council and other organizations to promote this issue. ${ }^{34}$ The website allows users to search for places where they can receive digital literacy training, with the search results primarily displaying local public library branches. However, despite pointing users to public libraries for such training, Connect2Compete currently only helps to fund such training in limited cases. While this program provides a strong model for raising awareness about digital inclusion, it is unlikely to provide infrastructure resources to fully bridge the gap between rural and nonrural communities in the near future. While the FCC has been innovative by soliciting private funds to prevent Connect2Compete from using any taxpayer funds, these private funds will not replace the need for government funds for public libraries throughout the nation, nor is private funding likely to continue indefinitely. Indeed, "while governments at all levels are relying on public libraries to ensure digital inclusion, the same governments are reducing the funding of the very libraries that are being relied on." 35 The following section will detail how decreasing funding and limited resources have contributed to the digital divide between rural and nonrural libraries.

\section{Rural Libraries and Barriers to Promoting Digital Inclusion}

When the Internet was emerging in the 1990s, "public libraries essentially experimented with public-access Internet and computer services, largely absorbing this service into existing service 
and resource provision without substantial consideration of the management, facilities, staffing, and other implications of public-access technology services and resources." 36 While some libraries have increased their funding levels to match these challenges, most funding agencies have not recognized the costs or value of additional services that public libraries now offer in a wired nation. This section discusses the reasons why rural libraries have not been able to offer the same level of service nonrural library patrons routinely expect.

\section{Funding Inadequacies for Rural Libraries}

Rural libraries face challenges from their problematic funding structure. Sin noted that for public libraries, "on average, the local government provided $76.6 \%$ of the funding; the state, $8.7 \%$; the federal government, $0.7 \%$; and other sources, $13.9 \%$." 37 This is a particular problem for rural libraries since, as Holt explained, "if cities and suburbs had to survive on the extraordinarily low taxes on agricultural property, the urban/suburban public sector would have service levels so low that most officials would turn away in disgust." 38 This lack of local revenue for all public services-including libraries-in rural areas is exacerbated by the continuing population decrease in small towns and the desirability of such locales for retiring seniors, who prefer to live in areas with low taxes because of limited incomes. ${ }^{39}$ In other words, public library funding structures that place local governments at the forefront of budgeting plans put rural libraries at a serious disadvantage and promote a digital divide between rural and nonrural areas.

Holt notes, "It is the legitimate function of state government to make things right. State governments, after all, are of a size and scale that historically allows them to perform as equity agencies for locales." 40 Indeed, the averages for funding sources cited above can vary, and state and federal governments have attempted to dampen the funding inequities between rural and nonrural libraries. One example is the federal E-rate program, established under the Telecommunications Act of 1996 to provide schools, libraries, and healthcare providers with a discounted "education rate" for communication technologies, including Internet technologies. ${ }^{41}$ While this has subsidized part of the Internet service costs for libraries throughout the nation, many libraries do not apply because they do not know they are eligible or the application process is too complicated. Some rural libraries have had the advantage of their state library systems applying on their behalf, but even when funding is provided this only covers parts of the libraries' connection and equipment costs. And, according to the PLFTAS survey, only $61.5 \%$ of rural libraries received E-rate funds, compared to $75.0 \%$ of urban libraries, showing the program does not favor the class of libraries with the greatest connectivity issues. ${ }^{42}$

Likewise, as noted above, the federal government designated $\$ 7.2$ billion from the American Recovery and Reinvestment Act of 2009 for improving broadband access throughout the nation, with funding designated for rural areas and public libraries in general. These improvements will take time, though, and will not fully compensate for the lack of local funds for rural libraries or rural libraries not receiving nearly as much in nongovernmental funds as nonrural libraries. ${ }^{43}$ Additionally, while local governments in some areas have created their own broadband 
infrastructure to compensate for corporate providers' unwillingness to expand to some areas due to inadequate predicted profits, nineteen state governments banned such practices due to lobbying efforts from the broadband industry. ${ }^{44}$ The corporations that lobbied for these laws feared that if this becomes common practice, local governments could offer low enough pricing to compete against for-profit services. While this may be a legitimate concern, the end result of this legislation is local governments-including rural governments-in some states being legally blocked from allocating funds to solve the market failure that has prevented corporate providers from adequately expanding into rural areas. Therefore public libraries' funding and resource structures are inherently stacked against rural institutions. While E-Rate and other federal and state programs may mitigate the problem, the ultimate solution needs to be a restructuring of library funding models that takes the primary burden off struggling local governments or at least increases state and federal contributions.

In a seminal article on rural libraries and the technology written in 1995, Vavrek noted that "public libraries cannot survive by only appealing to those who are least likely to be able to pay to support the library. While visions of the homeless person using the Internet to locate information is both compassionate and within the social role of the public library, can the library afford to provide this access?" 45 Beyond patrons not being open to assisting less fortunate individuals, Vavrek suggested attempts to diversify library services-including introducing Internet technology services, which was novel at the time-could distract resources from libraries' established services that have traditionally appealed to all income classes and, with this, erode public support for these institutions. The Pew Home Broadband 2010 survey show Vavrek's thoughts on this matter were prescient, as $53 \%$ of survey respondents believed the government either should not support broadband expansion or that this should not be a very important priority. ${ }^{46}$ The benefits of greater broadband access and relevant service support may seem obvious to those who are intimate with this matter, but much of the public does not see the importance of expanding such services. If rural librarians cannot fight these perceptions and convince traditional library users and the general public of the importance of these services, then they will probably not be able to reverse these negative trends. Unfortunately, rural libraries lack the time, resources, and data to lobby the public on these matters.

\section{Staffing and Training Problems for Rural Librarians}

A lack of funding and resources affect not only rural public libraries, but also rural public librarians. In a study that illustrated such issues, Flatley and Wyman surveyed a random sample of libraries in extremely rural areas, with their service population baseline being 2,500 as opposed to the 25,000 threshold noted above. ${ }^{47}$ While the data they collected are somewhat dated (the survey was conducted in 2007), this study still deserves special attention because similar data have not been collected more recently or by other authors.

The authors found that $80 \%$ of rural libraries have only a single full-time employee, and $50 \%$ have two or less paid employees when full- and part-time employees are considered. ${ }^{48}$ These 
employees are underpaid compared to the national average, with $72 \%$ reporting they earned $\$ 12.99$ or less per hour. ${ }^{49}$ When asked why they believed their pay was relatively low, more than half (53\%) of rural librarians responded it was because their communities lacked funds, demonstrating the structure of local funding being more important than state and federal funding to librarians' salaries. ${ }^{50}$

Flatley and Wyman also found that only 14\% of these employees held MLS degrees, with 32\% having achieved bachelor's degrees and 37\% having completed only a high school diploma. ${ }^{51}$ As one would expect in relation to most rural librarians not having professional training before entering the field, many of these individuals applied for their first library career because they saw a position advertised for their local library and it offered better pay than most other local jobs. While many rural librarians entered the profession because of reasons other than a desire to become librarians, the data suggest these individuals are capable and enthusiastic about their jobs. Almost half (47\%) of rural librarians had worked in the field for more than a decade, with an additional $22 \%$ having been librarians for six to ten years. ${ }^{52}$ Two-thirds $(66 \%)$ of survey respondents stated they intended to remain librarians until retirement age, and $97 \%$ responded they were very satisfied or somewhat satisfied with their careers. ${ }^{53}$ Additionally, despite the relatively low pay for library positions, this was not the most common complaint rural librarians had about their jobs. Instead, while $27 \%$ found low pay to be the greatest issue they faced, $29 \%$ felt a lack of funds for new materials was a greater problem. ${ }^{54}$

Therefore, while certain technological issues in rural public libraries-such as the lack of technological training courses for patrons - can be framed accurately as a problem involving rural librarians, these problems should not be framed as the librarians' fault. With current staffing levels, rural librarians do not have as much available staff time to provide training courses and one-on-one training as their suburban and urban counterparts. These librarians may also lack the knowledge and experience to train others in technological skills, and their libraries may lack the funds to help them acquire these abilities. These factors are outside of these librarians' control, however, and "no matter how hard LIS professionals try, one cannot expect public library systems (especially those in less-advantaged neighborhoods) to bridge the information gap when the libraries are themselves underfunded and understaffed." 55 Considering typical rural librarians' high dedication levels, one can assume they would be willing to remedy information gaps if they first had the resources to fix their libraries' skill, funding, and staffing gaps.

\section{POSSIBLE SOLUTIONS}

Rural libraries face the dual issue of a lack of resources to allow librarians enough time to advocate for their branches and a lack of data that advocates can use to show funders these libraries' value to their communities. As a solution for the latter problem, Sin suggested that library and information science (LIS) scholars and other prominent figures in the field begin a dialogue with underfunded libraries - including rural institutions - to work with librarians to gather, process, and interpret data on libraries' needs and libraries' effects on their 
communities. ${ }^{56}$ This would have the dual benefit of giving librarians better information with which they could focus their services for maximum value and providing graduate-student and professional-level researchers with a stronger understanding of their field. The authors of this article would like to expand on this slightly to suggest that any researchers who draft scholarly papers and presentations from data collected from work with underfunded libraries should feel obligated to assist libraries in using this data for their own benefit. Scholars are likely to be in a better position to advocate for libraries with which they collaborate than time-and resourcestrapped librarians, and they should feel an ethical responsibility to do so after reaping the benefits of research.

More rural librarians also need the skills to empower them to lead technological training courses for patrons, gather data to better understand how to best optimize their services, and lobby for greater funding at the local level. Mehra et al. of the School of Information Sciences at the University of Tennessee attempted to remedy this problem to a limited degree with a program they launched in June 2010 with funding from the IMLS Laura Bush 21st Century Librarian Program. ${ }^{57}$ The researchers used this funding to provide full scholarships-including laptop computers and funds for books - to sixteen rural librarians already working in the South and Central Appalachia regions, allowing them to earn an MLS degree in two years of part-time study. The researchers had previously conducted a qualitative survey of rural librarians in Tennessee to determine the training and resource needs of rural librarians, ${ }^{58}$ and they used these data to form a customized MLS program for the scholarship students. This included courses focusing on strong technical competencies, service evaluation, grant writing, and other courses of particular relevance to the rural environment.

Likewise, Georgia uses state funds to pay the salaries of many experienced librarians with MLS degrees throughout the state, thereby lifting the burden of affording such individuals off cashstrapped counties and municipalities. ${ }^{59}$ However, as this system develops in Georgia, state funding is still limited and there have been state funding cuts to other areas, such as materials and infrastructure, to allow for an increase in state-funded professional librarians. ${ }^{60}$ Therefore, while this appears to be a promising model that can be of particular benefit to rural residents of the state, further study is needed to determine its overall effects.

With an estimate of more than 8,000 rural public libraries operating in the United States, ${ }^{61}$ it would be impossible to find the resources to provide the large majority of librarians without an MLS at these locations with the full training needed to earn the degree. Even if such funding were available, a large portion - if not the majority - of these resources could be put to better use by improving rural libraries' technological infrastructure, increasing salaries, and growing collections. Therefore, while the MLS may remain the gold standard for library professionalism, it is not a realistic goal for many experienced and dedicated librarians throughout the country. Instead, a more realistic program on a larger scale may be to provide rural librarians with targeted online and in-person training to enhance the skills they feel they need to be more successful. Faculty and 
graduate students in LIS academic programs are perhaps the most capable people to lead such training, and they are likely more capable of writing grant proposals to cover the costs of such programs than the rural librarians they could assist. Mehra et al. have shown promising progress in this direction, ${ }^{62}$ and by removing the MLS goal (or only expecting it in limited cases), their work could easily be emulated to help LIS educators empower librarians throughout the nation.

Connect2Compete, as detailed above, also has the potential to provide a training model for public librarians. The organization plans to create a "Digital Literacy Corps," comprising individuals who will help train portions of the public in basic digital literacy skills. ${ }^{63}$ While this program is still in its early phases, the organization plans to include librarians among this Corps, training them to be better able to train others. Once again, this will be achieved through private funds donated by corporate partners. This is certainly a noble effort and will likely benefit many libraries and their patrons, but "having access to training and being able to take advantage of training are two separate things." 64

Connect2Compete, DigitalLiteracy.gov, and other organizations already provide some resources to help rural librarians understand digital literacy issues and provide better training, but librarians have limited time to familiarize themselves with these sources when dealing with their daily duties. For librarians to use current, future, or more refined training resources, the problem of low staffing — and its cause, low funding — must be addressed. Since many rural librarians lack the skill or, more importantly, time to lobby for their own libraries, this is a significant area where partner organizations can help. Whether these partners are university departments as envisioned by Mehra et al. and Sin or individuals funded by private donations in the Connect2Compete model is inconsequential. The important issue is that if these partner groups want to truly help rural libraries bridge the digital divide, these groups will have to contribute a significant portion of their efforts to lobbying to increase library funding enough to improve infrastructure and increase staffing —and, through this, staff time-for training and assisting patrons.

As discussed above, the BTOP program has had success both in increasing technological infrastructure and human infrastructure, with grant funding being used in some cases to bring in temporary staff that is capable of training patrons in digital literacy and to increase training opportunities for patrons using existing staff. Given the information above, BTOP's holistic approach is certainly encouraging, and the program's use of federal funds has shown how resources from above the local level can serve as an equalizing force. The temporary nature and limited funding of this program, however, make it important to remember this cannot be considered as the primary solution to the digital inclusion problem.

\section{CONCLUSION}

Many rural public libraries are the only providers of free broadband Internet service and computer terminals for their communities, with these communities having the lowest average proportion of homes with broadband connections. With the Internet being essential to receive 
important government services and to apply for jobs with some of the largest and most ubiquitous employers throughout the nation, the value of the services offered by these libraries cannot be understated.

The basic public library funding structure needs to be modified to close the digital inclusion gap between rural and more populated areas. Even if local governments remain the primary funding source for public libraries, this contribution cannot remain grossly disproportionate when compared to state and federal support. State and federal governments are already seeing savings by moving access to government services and information online, and these governments will benefit with the better employment rates and better employee competency that comes with a digitally inclusive society. Since these governments share in the benefits of digital inclusion, they must also share in the costs.

Some programs have shown promising results in bolstering rural public libraries and, though this, improving this nation's digital inclusion. These results range from large-scale programs such as BTOP to smaller programs such as the MLS education program initiated by Mehra et al. A common element of many of these programs, though, is their temporary nature, showing that funders are not recognizing that as technological innovation continues, new problems in digital inclusion will emerge. For government decision makers to understand the ongoing nature of the digital inclusion problem, rural public librarians and their allies-including academics and other stakeholderswill need to gather better data and provide better advocacy.

\section{REFERENCES}

1. "FY2011 Public Library (Public Use) Data Files," Institute of Museum and Library Services, http://www.imls.gov/research/pls data files.aspx.

2. John Carlo Bertot etal., 2011-2012 Public Library Funding and Technology Access Survey: Survey Findings and Results (College Park, MD: Information Policy and Access Center, 2012), http://ipac.umd.edu/sites/default/files/publications/2012 plftas.pdf.

3. The studies originally began as the Public Libraries and the Internet survey series until 2006 through various funding sources, at which time they became part of the Public Library Funding and Technology Access study (http://www.ala.org/plinternetfunding), funded by the American Library Association and the Bill \& Melinda Gates Foundation.

4. John Carlo Bertot et al., "Public Libraries and the Internet: An Evolutionary Perspective," Library Technology Reports 47, no. 6 (2011): 7-8.

5. Paul T. Jaeger et al., "The Intersection of Public Policy and Public Access: Digital Divides, Digital Literacy, Digital Inclusion, and Public Libraries," Public Library Quarterly 31, no. 1 (2012): 1-20.

6. Bertot et al., 2011-2012 Public Library Funding and Technology Access Survey. 
7. Aaron Smith, Home Broadband 2010 (Washington, DC: Pew Research Center, 2010): 8, http://www.pewInternet.org/ /media//Files/Reports/2010/Home\%20broadband\%20201 $\underline{0 . p d f}$.

8. Federal Communications Commission, Connecting America: The National Broadband Plan (Washington, DC: Federal Communications Commission, 2009): xi-xiii, http://download.broadband.gov/plan/national-broadband-plan.pdf.

9. Aaron Smith, Home Broadband 2010, 5.

10. John Carlo Bertot, Charles R. McClure, and Paul T. Jaeger, "The Impacts of Free Public Internet Access on Public Library Patrons and Communities," Library Quarterly 78, no. 3 (2008): 286; Bertot et al., "Public Libraries and the Internet," 12-13.

11. Jaeger et al., “The Intersection of Public Policy and Public Access,” 1-20.

12. US Public Libraries and the Broadband Technology Opportunities Program (BTOP). (Washington, DC: American Library Association, 2013): 1-2, http://www.districtdispatch.org/wp-content/uploads/2013/02/ALA BTOP Report.pdf.

13. Ibid., 18.

14. "States Continue to Feel Recession's Impact," Center on Budget and Policy Priorities, last modified June 27, 2012, http://www.cbpp.org/cms/index.cfm?fa=view\&id=711.

15. Deanne W. Swan et al., Public Libraries Survey: Fiscal Year 2010 (IMLS-2013-PLS-01) (Washington, DC: Institute of Museum and Library Services, 2010)

16. Paul T. Jaeger et al., "Public Libraries and Internet Access Across the United States: A Comparison by State from 2004 to 2006," Information Technology \& Libraries 26, no. 2 (2007): 4-14, http://dx.doi.org/10.6017/ital.v26i2.3277.

17. Natalie Greene Taylor et al., "Public Libraries in the New Economy: 21st Century Skills, the Internet, and Community Needs," Public Library Quarterly 31, no. 3 (2012): 191-219.

18. Bharat Mehra et al., "What is the Value of LIS Education? A Qualitative Study of the Perspectives of Tennessee's Rural Librarians," Journal of Education for Library \& Information Science 52, no. 4 (2011): 272.

19. Bertot et al., 2011-2012 Public Library Funding and Technology Access Survey, 15.

20. Ibid., 22.

21. Ibid., 46.

22. Bertot, "Public Access Technologies in Public Libraries," 88.

23. Bertot et al., 2011-2012 Public Library Funding and Technology Access Survey, 21.

24. Ibid., 29. 
25. Ibid., 42-45.

26. Mehra et al., "What is the Value of LIS Education?” 271-72.

27. Bertot et al., 2011-2012 Public Library Funding and Technology Access Survey, 36.

28. Paul T. Jaeger and John Carlo Bertot, "Responsibility Rolls Down: Public Libraries and the Social and Policy Obligations of Ensuring Access to E-government and Government Information," Public Library Quarterly 30, no. 2 (2011): 91-116.

29. Ibid., 100.

30. The Obama Administration's Commitment to Open Government: A Status Report (Washington: Government Printing Office, 2013): 4-7, http://www.whitehouse.gov/sites/default/files/opengov report.pdf.

31. Barack Obama, Digital Government: Building a 21st Century Platform to Better Serve the American People (Washington, DC: Office of Management and Budget, 2012), http://www.wh.gov/digitalgov/pdf.

32. "Find Educator Tools," DigitalLiteracy.gov, http://www.digitalliteracy.gov/content/educator.

33. “About Us," EveryoneOn, http://www.everyoneon.org/c2c.

34. Ad Council, “Ad Council \& Connect2Compete Launch Nationwide PSA Campaign to Increase Digital Literacy for 62 Million Americans," press release, March 21, 2013, http://www.adcouncil.org/News-Events/Press-Releases/Ad-Council-Connect2CompeteLaunch-Nationwide-PSA-Campaign-to-Increase-Digital-Literacy-for-62-Million-Americans.

35. Jaeger et al., "Public Libraries and Internet Access," 14.

36. Bertot, "Public Access Technologies in Public Libraries," 81.

37. Sei-Ching Joanna Sin, "Neighborhood Disparities in Access to Information Resources: Measuring and Mapping U.S. Public Libraries' Funding and Service Landscapes," Library \& Information Science Research 33, no. 1 (2011): 45.

38. Glenn E. Holt, “A Viable Future for Small and Rural Libraries,” Public Library Quarterly 28, no. 4 (2009): 288.

39. Ibid., 288-89.

40. Ibid., 289.

41. Paul T. Jaeger, Charles R. McClure, and John Carlo Bertot, "The E-rate Program and Libraries and Library Consortia, 2000-2004: Trends and Issues," Information Technology \& Libraries 24, no. 2 (2005): 57-67.

42. Bertot et al., 2011-2012 Public Library Funding and Technology Access Survey, 61.

43. Sin, "Neighborhood Disparities in Access," 51. 
44. Olivier Sylvain, “Broadband Localism,” Ohio State Law Journal 73, no. 4 (2012): 20-24.

45. Bernard Vavrek, "Rural Information Needs and the Role of the Public Library," Library Trends 44, no. 1 (1995): 26.

46. Aaron Smith, Home Broadband 2010, 2.

47. Robert Flatley and Andrea Wyman, "Changes in Rural Libraries and Librarianship: A Comparative Survey," Public Library Quarterly 28, no. 1 (2009): 25-26.

48. Ibid., 34 .

49. Ibid., 35 .

50. Ibid., 28.

51. Ibid., 33.

52. Ibid., 26.

53. Ibid., 29.

54. Ibid., 30.

55. Sin, “Neighborhood Disparities in Access," 50.

56. Ibid., 51.

57. Bharat Mehra et al., "Collaborations Between LIS Education and Rural Libraries in the Southern and Central Appalachia: Improving Librarian Technology Literacy and Management Training," Journal of Education for Library \& Information Science 52, no. 3 (2011): 238-47.

58. Mehra et al., "What is the Value of LIS Education?"

59. “State Paid Position Guidelines," last updated August 2013, http://www.georgialibraries.org/lib/stategrants accounting/Official_State_Paid_Position_Gui delines-Updated-August-2013.pdf.

60. Bob Warburton, “Georgia Tweaks State Funding Formula to Prioritize Librarians," Library Journal, February 2, 2014, http://lj.libraryjournal.com/2014/02/budgets-funding/georgiatweaks-state-funding-formula-to-prioritize-librarians.

61. Bertot et al., 2011-2012 Public Library Funding and Technology Access Survey, 14.

62. Mehra et al., "Collaborations Between LIS Education and Rural Libraries"; Mehra et al., "What is the Value of LIS Education?"

63. Institute of Museum and Library Services, "IMLS Announces Grant to Support Libraries' Roles in National Broadband Adoption Efforts," press release, June 14, 2012, http://www.imls.gov/imls announces grant to support libraries roles in national broadban d adoption efforts.aspx. 
64. Bertot, "Public Access Technologies in Public Libraries," 88. 